\title{
Petroleum Engineering Education in Nigeria: Development, Challenges and Prospects
}

\author{
IYEKE, Solomon Dibiamaka ${ }^{1^{*}}$, BELLO, Kelani Olafinhan ${ }^{2}$ \\ ${ }^{1}$ Department of Civil Engineering, Faculty of Engineering, University of Benin, Nigeria. \\ ${ }^{2}$ Department of Petroleum Engineering, Faculty of Engineering, University of Benin, Nigeria.
}

\author{
*Corresponding Author: IYEKE, Solomon Dibiamaka, Department of Civil Engineering, Faculty of \\ Engineering, University of Benin, Nigeria.
}

\begin{abstract}
The petroleum sector plays an important role in shaping the economy and political aspects of Nigeria. There is the need to build the required manpower equipped to handle the challenges in this sector. The study of petroleum engineering started in the University of Ibadan in 1972 and since then, a total of twenty-one accredited universities now offer petroleum engineering as a course. However, there are challenges facing petroleum engineering education in Nigeria such as lack of adequate facilities, poor funding, staff shortage etc. These issues are being addressed by the government through various interventions to help improve the quality of petroleum engineering education in Nigeria.
\end{abstract}

Keywords: Petroleum Engineering, Nigeria, Challenges, Prospects, University

\section{History of Petroleum Engineering Education in Nigeria}

The exploration of petroleum resources in Nigeria began in 1908, with Tar Sand deposit prospecting in the South-Western Nigeria by Nigerian Bitumen Corporation (Ite et al., 2013).The start of World War I ended the exploration efforts in 1914 and in 1946 after World War II, oil investigation recommenced in the Niger Delta region of Nigeria with several oil exploratory wells drilled in 1951 by Shell D'Arcy. The Niger Delta region is located on the South-South geopolitical zone of Nigeria and on the apex of the Gulf of Guinea on the west coast of Africa (Doust, 1990). The region comprises of nine oil-producing states (Abia, Akwa Ibom, Bayelsa, Cross River, Delta, Edo, Ondo, Imo and Rivers), over 900 producing oil wells and numerous facilities for petroleum production (Osuji and Onojake, 2004). The first commercial oil field was discovered at Oloibiri in 1956 by Shell D'Arcy (later Shell-British Petroleum) and another field was also found at Afam (Vassiliou, 2009). Exportation of crude oil from these fields started in 1958(Pearson, 1970). In order to facilitate accelerated petroleum exploration and production in Nigeria, the sole concession policy was abolished and exclusive exploration right introduced after Nigeria became an independent nation On October 1, 1960 (Bamberg, 2000). As a result of the increase dominance of the Nigerian economy by petroleum sector, there was a need to develop locally, technical qualified Nigerians to operate in the oil industry. This led to the establishment of higher institutions of learning for the training of Nigerians in the field of petroleum engineering.

Petroleum Engineering has been defined as the practical application of the basic sciences of physics, chemistry, mathematics and geology, and all the engineering sciences to the development, recovery and processing of petroleum (Department of Petroleum and Gas Engineering UNIPORT, 2016). The University of Ibadan was the first university in Nigeria to establish a petroleum engineering department. The Department was formally established in 1972 as one of the foundation departments of the Faculty of Technology (Faculty of Technology UI, 2013). The Department was created to assist the Nigerian Government achieve industrialization and self-reliance in the oil industry by training and producing of Petroleum Engineering Graduates with excellent academic standards and adequate competence to tackle the problems of the industry. This was followed with the establishment of the Department of Chemical and Petroleum Engineering, University of Benin in 1973/1974 academic session. The Department was later divided into Department of Chemical Engineering and Department of Petroleum Engineering in 1984 (Faculty of Engineering UNIBEN, 2008). The Department of Petroleum Engineering, University of Port Harcourt was established in 1979. The Department of Petroleum Engineering has now been upgraded to Petroleum and Gas Engineering Department. 
Petroleum engineering education in Nigeria has since experience a tremendous increase, with the number of accredited tertiary institution offering the course risen to about Twenty-One (21) Universities. The list of accredited Universities offering Petroleum Engineering course in Nigeria as indicated in JAMB Brochure 2018 is presented in Table 1 and their geographical location shown in Figure 1.

Table1. List of Universities Offering Petroleum Engineering Course in Nigeria

\begin{tabular}{|c|c|c|c|c|}
\hline S/N & Name of University & Abbreviation & Location & Funding \\
\hline 1 & Abubakar Tafawa Balewa University & ATBU & Bauchi, Bauchi State & Federal \\
\hline 2 & Afe Babalola University & ABUAD & Ado-Ekiti, Ekiti State & Private \\
\hline 3 & Bayero University & BUK & Kano, Kano State & Federal \\
\hline 4 & Baze University & BU & FCT, Abuja & Private \\
\hline 5 & Covenant University & CU & Ota, Ogun state & Private \\
\hline 6 & Alex Ekwueme Federal University & FUNAI & Ndufu-Alike, Ebonyi State & Federal \\
\hline 7 & Federal University of Technology Owerri & FUTO & Owerri, Imo State & Federal \\
\hline 8 & Gregory University & GUU & Uturu, Abia State & Private \\
\hline 9 & Federal University of Petroleum & FUPRE & Effurun, Delta State & Federal \\
& Resources, Effurun & & & \\
\hline $10^{*}$ & Federal Univeristy & FUOTUOKE & Otuoke, Bayelsa & Federal \\
\hline 11 & Iginedion University & IUO & Okada, Edo State & Private \\
\hline 12 & Madonna University & Okija, Anambra State & Private \\
\hline 13 & Niger Delta University & NDU & Wilberforce Island, Bayelsa State & State \\
\hline $14^{*}$ & Nigeria Turkish Nile University & NTNU & Abuja & Private \\
\hline 15 & Ondo State University of Science and & OSUSTECH & Okitipupa, Ondo State & State \\
& Technology & & & \\
\hline 16 & River state University of Science and & RSUST & Port-Harcourt, Rivers State & State \\
& Technology & UNIBEN & Benin City,, Edo State & Federal \\
\hline 17 & University of Benin & UI & Ibadan, Oyo State & Federal \\
\hline 18 & University of Ibadan & UNILAG & Akoka, Lagos State & Federal \\
\hline $19^{*}$ & University of Lagos & UNIPORT & Port-Harcourt, Rivers State & Federal \\
\hline $20^{*}$ & University of Port Harcourt & UNIUYO & Uyo, Akwa Ibom State & Federal \\
\hline 21 & University of Uyo & &
\end{tabular}

- Offers Petroleum and Gas engineering

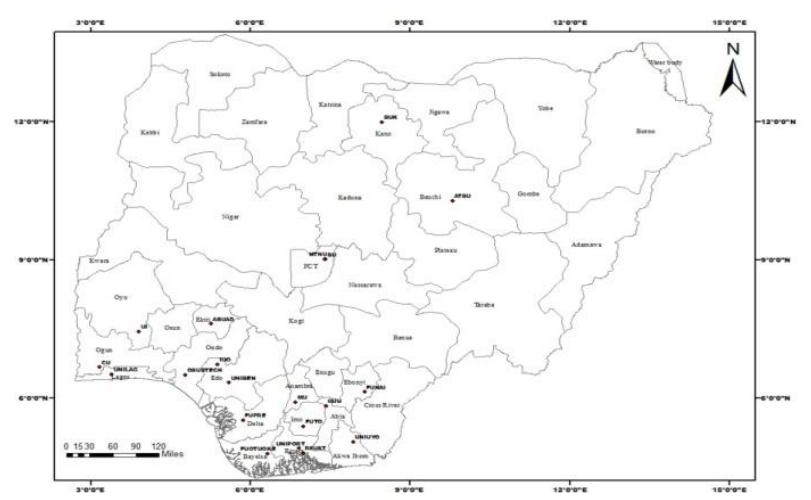

Figure1. Map of Nigeria Showing the Spatial Distribution of Universities Offering Petroleum Engineering Education in Nigeria

The spatial distribution of the universities offering petroleum engineering education in Nigeria shows that two federal and two private universities are located in the north-central zone, two federal, one state and two private universities are situated in south - west zone of Nigeria. Also, two federal and two private universities are positioned in the south - east zone of Nigeria. In the south - south zone of Nigeria, there are two state and one private universities.

\section{ENTRY REQUIREMENTS FOR PETROLEUM ENGINEERING IN NIGERIAN TERTIARY INSTITUTIONS}

\subsection{Ordinary Level Requirements}

The ordinary level entry requirements to study petroleum engineering in any Nigerian tertiary institutions as stipulated by the regulatory authorities is at least five Ordinary Level credit passes in West Africa Examination Council (WAEC), Senior School Certificate Examination (SSCE), National Examination Council (NECO) or any of their recognized equivalent at not more than two sittings. The 
subjects should include Physics, Chemistry, Mathematics, English Language and one science subject (JAMB, 2018).

\subsection{Unified Tertiary Matriculation Examination (UTME) Requirements}

The UTME subjects' entry requirements to study petroleum engineering in any Nigerian tertiary institutions are English Language, Physics, Chemistry and Mathematics (JAMB, 2018). The cut-off score requirement for university and polytechnics are determined every year by the candidates' overall performance. Thus, most times, JAMB usually gives a cut - off score of 160 or $\mathbf{1 8 0}$ as the admission cut-off mark for Universities. However, based on internal requirements, individual university is allowed to determine the entry cut-off score.

\section{Challenges of Petroleum Engineering Education in Nigeria}

There are several challenges encountered by Nigerian tertiary institutions offering petroleum engineering program. These challenges are discussed as follows:

\subsection{Funding of Petroleum Engineering Education in Nigeria}

Many researchers have reported the lack of funding as one of the major factors militating against engineering education in Nigeria (Okujagu, 2013; Idris and Rajuddin, 2012; Akintola et al., 2002; Oloyede, et al., 2017), with the level of funding at $5-6 \%$ of the national budget as against $26 \%$ recommended by UNESCO (Okujagu, 2013). Lack of adequate fundings has resulted in poorly equipped workshops and laboratories in technological institutions (Sofolohan, 2008), severe shortage of consumables and equipment (Owolabi and Rafiu, 2010) and sometimes the equipment are obsolete for training students for the challenges of modern society. There is also the absence of stable power supply to operate the various laboratories, machines power and computer where available. All these have led to the policy to control university admission based on carrying capacities on Nigerian University system (Kolo, 2007). Despite the poor allocation of funds to public university, those concerned with the judicious implementation of university programs often engage in corrupt practices because of lack of proper monitoring of university income and expenditure (Akpan, 2007; Ogbondah, 2010). Also, the lack of funds has restricted greatly ICT integration in petroleum engineering education. As noted by Ololube et al., (2013), automation of library and information systems provides effective and efficient information services delivery. E-learning, E-library, E-books, etc, are essential in petroleum engineering education today. However, a study carried out by Okorie, Agabi and Uche (2005) to examine the extent of public and private universities in Nigeria utilization of ICT application in learning, revealed that actual application is moderate for private universities and low for public universities. The inadequate funding of research programmer has led to decline in the quality of research in petroleum engineering. Research in the higher institutions is necessary for the development of the individual and society. Okafor (2001) argued along the same line when he stated that lack of funds is affecting research in the universities and that there is no indication that this problem will not continue in the future.

\subsection{University-Industrial Linkages}

It has been reported in Mahmud et al., (2012) that the major qualities of a good engineer are technical ability, imagination, industry partnership and solid judgment. Student's creativity from petroleum engineering education is enhanced through practical education in conjunction with industries. This can be achieved through collaboration between academia and industries. These collaborations can be in the form of research grants, seminars, conferences, seminars, publications etc. In the Nigeria education system, such memorandum of understanding between universities and industries are entirely not present (Onwuka, 2009).

\subsection{Petroleum Engineering Education Lecturers in Nigeria}

Many universities offering petroleum engineering course are inadequately staffed. Shu'ara (2010) has reported that the low number of academic staff with $\mathrm{PhD}$ qualification is affecting engineering education in Nigeria. Most of these staff do not have professional membership and belong to the junior academic cadre with no work and research experiences. Mahomud et al., (2012), is of the opinion that the requirement for employment of engineering lecturers should be a combination of good grades and industry related work experience. In this way lecturers are able to impart to the students both technically and practically. Most professors and senior lecturers have left the frustration of university life into more challenging and rewarding sectors of the economy, while others have left the country for greener pastures (Idris and Rajuddin, 2012). This has led to diminishing scope of 
mentoring junior researchers. Also, the lack of human capacity development of lecturers in petroleum engineering has further worsened the situation. The result of the faculty exodus is observed in the quality of petroleum engineering graduates that our universities produce.

\subsection{Strikes Actions of Public Universities}

There have been several strikes in Nigerian Universities embarked by the Academic Staff Union of Universities (ASUU) (Aidelunuoghene,2014; Ugwuona,2016; Ogbette et al., 2017), occasioned by disagreement between government and the union. Academic activities are usually suspended for a considerable period (Table 2), leading to disruption in the students reading abilities.

Table2. History of Asuu strike in Nigeria from 1999-till date

\begin{tabular}{|c|c|c|}
\hline S/N & Year & Duration \\
\hline 1 & 1999 & 5 months \\
\hline 2 & 2001 & 3 months \\
\hline 3 & 2002 & 2 weeks \\
\hline 4 & 2003 & 6 months \\
\hline 5 & 2005 & 2 weeks \\
\hline 6 & 2006 & 3 week \\
\hline 7 & 2007 & 1 week \\
\hline 8 & 2008 & 4 months \\
\hline 9 & 2009 & 5 months \\
\hline 10 & 2010 & 59 days \\
\hline 11 & 2011 & 5 months \\
\hline 12 & 2013 & 1 month \\
\hline 13 & 2017 & November 2018 - February 2019 \\
\hline 14 & 2018 & \\
\hline
\end{tabular}

These strikes have been known to affect petroleum engineering students studying in Nigeria universities, as effective learning is achieved through timely completion of academic course contents. It has been reported that strike action dampens student's development as it creates frustration, emotional and psychological trauma, lack of motivation etc. (Ogbette et al., 2017). Eventually, some students become certificates seekers than knowledge seekers.

\section{Prospects of Petroleum Engineering Education in Nigeria}

The efforts by various stakeholders in the Education sector towards the provision of good and quality education in Nigeria gives a prospect for a better and efficient education management system in the country. The engineering education has been enhanced by some of the following factors:

\subsection{Research, Staff Training, Teaching Facilities, Infrastructures and Equipment in Petroleum Engineering Education in the Universities}

There have been significant efforts by the Government to help increase the sources of funding to universities in the country. One of the most significant efforts of the Federal Government was the establishment of the Petroleum Technology Development Fund (PTDF) to train Nigerians for the oil and gas industry. PTDF was established by Act 25 of 1973 as amended in Cap 15 of 2000 to replace the former Gulf Oil Company Training Fund Act 1964 (Adekalu, et al., 2013). PTDF has established various programs like Oversea Scholarship Scheme (OSS), Local Scholarship Scheme (LSS), University's Endowment Programmers etc. Under the OSS and LSS programs staff and students of Nigeria tertiary institution have been trained at the Bachelor, Masters and $\mathrm{PhD}$ levels. There are annual budgetary allocations ranges from N14million to N20million per university to support professional chairs established in six universities to undertake research relevant to capacity building in the oil and gas industry (Bamiro and Adedeji, 2010). Another significant effort of the Federal Government was the creation of the Tertiary Education Trust Fund (TETFUND). TETFUND was formally established as Education Trust Fund (ETF) by the Education Tax Act No 7 of 1993 as amended by Act No 40 of 1998 (now repealed and replaced with Tertiary Education Trust Act 2011). It is an intervention agency which provides additional aid to public tertiary institutions mainly in human capacity and infrastructural development for tertiary education. Also, the Needs Assessment Intervention Fund in Nigerian Public Universities, in line with FG/ASUU Agreement seeks to revitalization the University system through the provision of funds to the tune of N1.3 trillion for a 
period of six (6) years (2013 - 2018) (NEEDS 2015). As a revitalization fund, the intervention is intended to, rehabilitate and upgrade the physical facilities for teaching and learning in the Universities and ensures upgrade of academic staff qualification through sponsorship for postgraduate studies within and outside Nigeria. The Science and Technology Education Post-Basic Project popularly known as STEP-B Project is for Science and Technology in tertiary institutions. The World Bank assisted Project in partnership with the Federal Ministry of Education (Abuja), seek to enhance collaborations between researchers in the public and private sectors, between Nigerian institutions and their partners internationally etc. ICT for education initiatives like Nigerian Universities Network (NUNet) Project and the Polytechnics Network (PolyNet) Project have been developed by Government through its education ministry and agencies.

\section{CONCLUSION}

In order to develop the required technical local manpower required for the petroleum sector. Currently, a total of twenty-one universities have established the Department of Petroleum Engineering in Nigeria. Seven of these universities are owned by private organizations three universities by State Governments of Edo, Bayelsa and Rivers and eleven universities by the Federal Government of Nigeria. Two Federal and two private Universities are located in the north - central zone of Nigeria. There are two federal. One state and two private universities situated in south - west zone of Nigeria. Also, two Federal and two private Universities are in the south - east zone of Nigeria. While, five federal, two state and one private Universities are in the south - south zone of Nigeria. The study of petroleum engineering in Nigeria is faced with several challenges like poor funding, inadequate facilities, manpower shortage etc. These issues go a long way in the determination of the quality of graduates for Nigeria petroleum industry. The governments through agencies like PTDF, TETFUND, STEP-B have been entrusted with revitalization of the education sector.

\section{REFERENCES}

[1] Adekalu, S. O., Oludeyi, O. S., Genty, K. I, and Wolo, A., (2013). Petroleum Technology Development Fund (PTDF) Mandates and Human Capacity Development in Nigeria: Benefits for Nigerian Youths. International Journal of Research in Management, 3 (5):67-77.

[2] Aidelunuoghene, S.O., (2014). ASUU Industrial Actions: Between ASUU and Government Is It an Issue of Rightness? Journal of Education and Practice, 5(6): 7 -17.

[3] Akintola, A.A., Aderounmu, G.A. and Owolarafe, O.K., (2002). Problems of engineering education and training in developing countries: Nigeria as a case study, European Journal of Engineering Education, 27 (4):393-400.

[4] Akpan, E. U. U. (2007). Educational reform and the Improvement of Educational standards in Nigeria. In Ozoji, E. D. Dala, B. Co., Mugu, Y., \& Mustapha A. Y (Eds) Nigerian education system: which way forward? Asaba: Nigerian Primary and Teacher Education Association (NPTEA) pp. 14-45.

[5] Bamberg, J., (2000). British Petroleum and Global Oil 1950-1975: The Challenge of Nationalism: Cambridge University Press.

[6] Bamiro, O.A. and O.S. Adedeji, 2010. Sustainable Financing of Tertiary Education in Nigeria. Ibadan. University Press, Ibadan.

[7] Crescentia NwaezeUgwuona, C. N., (2016). 2013 ASUU Strike Discourses in Nigeria: A Critical Discourse Analysis. Mediterranean Journal of Social Sciences, 7(2): 435-444

[8] Department of Petroleum and Gas Engineering UNIPORT (2016). University of Port Harcourt, Faculty of Engineering, Department of Petroleum and Gas Engineering Handbook for B. Eng Degree Programme 2016-2018. www.acadplan.uniport.edu.ng/images/handbook/petengr.pdf. Accessed on 5/12/2018

[9] Doust, H., (1990). Petroleum geology of the Niger Delta, Geological Society, London, Special Publications, 50(1):365-365.

[10] Faculty of Technology UI (2014). University of Ibadan, Faculty of Technology, Undergraduate Prospectus, 2014/2015. www.https://tech.ui.edu.ng/sites/default/files/Prospectus2015_0.pdf. Accessed on $5 / 12 / 2018$

[11] Faculty of Engineering UNIBEN (2008). Handbook, Faculty of Engineering, University of Benin, 20082010. Ambik Press, Benin City, Edo State.

[12] Idris, A. and Rajuddin, M., (2012). The Trend of Engineering Education in Nigerian Tertiary Institutions of Learning towards Achieving Technological Development. Procedia - Social and Behavioral Sciences $56: 730-736$. 
[13] Ite, A.E., Ibok, U. J., Ite, M.U., and Petters, S.W., (2013). Petroleum exploration and production: past and present environmental issues in the Nigeria's Niger Delta. American Journal of Environmental Protection, 1(4):78-90.

[14] JAMB, (2018). Joint Admissions and Matriculation Board, Guidelines for Admissions to First Degree, National Diploma (Nd), National Innovation Diploma (Nid) and Nigeria Certificate In Education (Nce) Courses and Programmes Ii Universities, Other Degree-Awarding Institutions, Monotechnics, Polytechnics, Innovation Enterprise Institutes and Colleges of Education in Nigeria 2017/2018 Session.

[15] Kolo, I. A. (2007). Reforms in the Nigerian Education System: The way forward. In Ozoji, E. D. Dala, B. G., Mugu, Y., and Mustapha A. Y (Eds) Nigerian Education System: which way Forward? Asaba: Nigerian Primary and Teacher Education Association (NPTEA) pp. 14-45.

[16] Mahmud, J.O., Mohd Ismail, M. S. and MohdTaib, J., (2012). Engineering Education and Product Design: Nigeria's Challenge. International Conference on Teaching and Learning in Higher Education (ICTLHE 2012) inconjunction with RCEE \& RHED 2012. Procedia - Social and Behavioral Sciences 56, 679 - 684.

[17] Ogbondah, L. (2010) Adequate funding of public universities in Nigeria for sustainable development, African journal of historical sciences in education, 6(2):322-323.

[18] Ogbette, A.S, Eke, I. E., Ori, O. E., (2017). Causes, effects and management of ASUU Strikes in Nigeria, 2003-2013. Journal of Research and Development, 3(3):14-23.

[19] Oloyede, A.A., Ajimotokan, H.A. and Faruk, N., (2017). Embracing the Future of Engineering Education in Nigeria: Teaching and Learning Challenges. Nigerian Journal of Technology, 36(4):991 - 1001.

[20] Okafor, C.N. (2001). University education in developing countries: The changing roles and future problems, journal of education development, 3(2):54 - 60 .

[21] Okorie, C.U, Agabi, O.G. and Uche, C.M., (2005). Application of information and communication technology (ICT) in the management of public and private universities. Nigeria journal of educational administration and planning 5(2):20-36.

[22] Okujagu, A.A., (2013). Marketing' Nigerian Education: Issues and Challenges. Academic Journal of Interdisciplinary Studies, 2(5):57-66.

[23] Ololube, N.P, Umunadi, K.E., and Kpolovie, R.J. (2013). Barriers to blended teaching and learning in subsahara Africa: Challenges for the next decade and beyond. In N.P. Ololube (Ed). Advancing Technology and educational development in emerging economies, Owerri. Hershey Educational Publishers.

[24] Onwuka, E.N.(2009).Reshaping engineering education curriculum to accommodate the current needs of Nigeria. Educational Research and Review, 4 (7):334-339.

[25] Osuji, L. C., and Onojake, C.M., (2004). Trace heavy metals associated with crude oil: A case study of Ebocha-8 oil-spill-polluted site in Niger Delta, Nigeria, Chemistry and Biodiversity, 1 (11):1708- 1715.

[26] Owolabi, R.U. and Rafiu, L. (2010). Chemical Engineering Education in Nigeria: Challenges and Prospects. International Journal of Chemical Engineering and Applications, 1(2):138-141.

[27] Pearson, S. R., (1970). Petroleum and the Nigerian Economy: Stanford University Press, 1970.

[28] Sofolohan, A. O., (2008). Curriculum implementation in Nigeria Education today, 3(1):54-57.

[29] Shu'ara, J. (2010). Higher Education Statistics-Nigeria Experience in Data Collection. Paper Presented at the UNESCO Institute of Statistics Workshop on Education Statistics in Anglophon Countries, Windhoek 17 th -21 st October.

[30] Vassiliou, S., (2009). The A to Z of the Petroleum Industry: Scarecrow Press.

Citation: IYEKE, Solomon Dibiamaka \& BELLO, Kelani Olafinhan, (2019). "Petroleum Engineering Education in Nigeria: Development, Challenges and Prospects", International Journal of Petroleum and Petrochemical Engineering (IJPPE), 5(1), pp.24-29, DOI: http://dx.doi.org/10.20431/2454-7980.0501004

Copyright: () 2019 Authors. This is an open-access article distributed under the terms of the Creative Commons Attribution License, which permits unrestricted use, distribution, and reproduction in any medium, provided the original author and source are credited 